\title{
THE CONCEPT OF GOD IN ALCINOUS
}

\begin{abstract}
The article explores some of Alcinous' stances on god from his work "The Handbook of Platonism", showing instances of influence by Plato, and of the general philosophical atmosphere of the middle Platonism. Some questions about the concept of Alcinous of the Primary god and the possibilities of anticipation of Plotinus' One are raised. The attention is directed towards Alcinous' concept of an ineffable god, graspable only through the intellect, and towards his focus on god's attributes, or rather on the ways in which some aspects of god are knowable through the abstraction of attributes. The ways of knowing god proposed by Alcinous are the negation or abstraction, analogy, and pre-eminence, and the issue whether these make his approach apophatic will be reviewed in the article, especially through his use of aphairesis (abstraction/negation).
\end{abstract}

Key words: ALCINOUS, GOD, INTELLECT, APHAIRESIS, KNOWLEDGE

This article offers an overview of some aspects of Alcinous' concept of god. ${ }^{1}$ Alcinous, a philosopher from the middle Platonism, about the life of whom almost nothing is known, is the author of The Handbook of Platonism, or On the doctrine of Plato (commonly known as Didaskalikos), one of the few extant works of the middle Platonist period, which was intended as a manual for teachers of Platonism. Alcinous was identified with the Platonist philosopher Albinus, the teacher of Galen, by Jacob Freudenthal in 1879 (Freudenthal, 1879). The validity of this identification remained unchallenged until 1974, when John Whittaker succesfully reformed Alcinous' identity. ${ }^{2}$ It appears

\footnotetext{
${ }^{1}$ Despite the frequent use of a majuscule " $G$ " in "god" in the translations of the works of Alcinous and in the secondary sources, a minuscule "g" will be used in this text for all instances of "god". The majuscule could be useful in distinguishing the Primary god from other gods, but it will be made clear in context (and the majuscule in the adjectives).

${ }^{2}$ He extensively analyses the problems of dating and authorship discovery in the Parisinus Graecus 1962 (Whittaker, 1974a, 320-354), to then focus on the author of Didaskalikos, discrediting Freudenthal's thesis and returning to the traditional view on Alcionus being the author of the Handbook. The conclusion of his thorough examination of the problem is that the works of Albinus listed in the pinax of Parisinus graecus 1962 are irretrievably and hopelessly lost, and that there is no viable proof for ascribing the Didaskalikos to Albinus (Whittaker, 1974b, 450-456). The following text might contain some interchangeable usage of both names, due to differences in the use in the secondary sources, but it should be assumed that "Alcinous" means "Albinus" and vice-versa.
} 
that Alcinous was not affiliated with the Academy, but can be considered as one of the best representatives of classical Platonism of the second century AD. His opus remained forgotten all through the fifteenth century, when Pietro Balbi (Petrus Balbus) took upon himself to translate it for Nicolas of Cusa. Apart from the Handbook of Platonism, a brief discussion and a classification of Plato's dialogues (Introduction, Eisagoge) also survived. The Handbook outlines versions of Plato's doctrines dominant in the second century, and it is significant that it also contains some associations with and references to Aristotle's opinions. ${ }^{3}$

In order to explain the principles and doctrines of theology, as a summary of Plato's philosophy, Alcinous begins with the basic elements (matter, forms and god), seeing this as a good direction to research the origins of the world and of man. ${ }^{4}$ If objects of intellection exist, neither sense-perceptible, nor participants in that which is sense-perceptible, but rather in certain primary objects of intellection, then, assumes Alcinous, there are primary objects of intellection in an absolute sense, just as there are primary objects of sense-perception (10. 1/164 9-14). Humans have so many sense impressions that even when they direct their minds toward the intelligible, they still retain sensible images in their imagination, so they imagine sizes, shapes and colours, unable to obtain a clear image of the intelligible. Contrary to this problematic human cognitive process, Alcinous postulates the gods, free of the shackles of sense perception, and capable of understanding the intelligible in a pure and untainted manner (10. 1/164 13-18). From this plural that Alcinous uses it is unclear what the status of the gods might be, but it can be safe to think that he uses a general divine principle to capture the meaning of their superiority over humans. According to Mortley, the description of the way the gods perceive things is the platonic equivalent of anti-anthropomorphic stance: the failure of common thinking lies also in the addition of the whole spatiotemporal dimension, not just the personal input (Mortley 1986b, 16-17). The deities think in a way that does not add volume, spatial extension or colour to the objects conceived, while humans reduce transcendent concepts to something easily perceptible by the mind's eye; the remote and the abstract is shattered by adding size. Mortley notices that this critique of overly concrete thinking is rather broader and more far-reaching than the Judeo-Christian attack to anthropomorphism, which concerns only the personalization of the divine. The Greek objection to concrete thinking, he explains, is because it adds to the transcendent entity not only the familiar concept of the person, but also all of the characteristics of the material reality in which the person resides (17).

The intellect is superior to the soul, and superior to the potential intellect is the actualized intellect that cognizes everything simultaneously and eternally. Assum-

\footnotetext{
${ }^{3}$ It is possible that this was never an intentional (or forced) similarity of doctrines, or even a sort of Plato-Aristotle merger, suggests Pierre Louis, but a result of the opinion that Aristotle was, in fact, a Platonist (see in Louis, 1945).

${ }^{4}$ 8.1/162 24-29. The edition of Alcinous, The Handbook of Platonism, John Dillon, trans,, 2002 (with translator's commentary) is used for all quotes and paraphrases of Alcinous.
} 
ing a soul-intellect hierarchy, and one of potential-actualized intellect, then there must be something superior to the actualized mind, something like a supreme principle $(10$, 2/164 19-24). In this line of argumentation, some of Aristotle's distinction between the human potential intellect and the active intellect of the cosmos as a whole can be sensed (De An. 3.5.430a10), but the relation between the soul and the intellect remains somewhat unclear. What Alcinous is probably trying to argue is that each of these intellects is immanent to something, and also in relation with that thing (and perhaps others), as well as that even the eternally active cosmic intellect has to have a logical predecessor, something (beyond the) underlying, a first principle. The actualized intellect is at times identified with the supreme god, and sometimes Alcinous makes a distinction between a god that is the cause for the intellect, and instead of, or more precisely, in addition to the god-forms-matter triad he postulates a primary god-intellectsoul triad. ${ }^{5}$

Alcinous propounds that the First god is the cause of everything, existing before anything else, the cause of the eternal activity of the intellect of the entire heaven. It acts on the intellect, without moving (like, for instance, the object of desire which remains unmoved itself). ${ }^{6}$ The primary intellect is the finest of all things, and therefore its object of cognition (intelligizing) must be supremely fine. Nothing is finer than this intellect, which means that it has to be everlastingly engaged in thinking itself and its own thoughts, and this activity (or rather its result) is Form (10.3/164 29-31). ${ }^{7}$ The first god is eternal, ineffable; it is self-perfect (in no respect deficient); eternally perfect and all-perfect (in every respect perfect). ${ }^{8}$ God is essentiality, truth, commensurability, beauty, good (10.3/ 164 32-35). These tentative ideas of a primary god, inspired by Timaeus, are an important feature in middle Platonism (Numenius'

\footnotetext{
${ }^{5}$ Merlan notices that Alcinous barely mentions that this primary god is the cause for the active intellect (the incessant activity of the intellect), which shows that Alcinous aims at raising this supreme god above the station of the intellect, but stops short just before he does so (Merlan, 1967, 66). ${ }^{6}$ It is possible that Alcinous is postulating a cosmic soul, along with the intellect of this cosmic soul (of the entire heaven) as a separate entity, and a First Cause, as a pre-underlying intellect/principle. This intellect seems to be modeled after the Aristotelian concept of the unmoved mover (unmoved, unmoving, and the object of desire, of striving, from Met 12. 7. 1072b3) - see also in Witt, 1937, 125. Alcinous refers to Plato's sun simile from Republic VI - this intellect acts on the comic intellect in the same way that the sun acts on the ability to see (see also footnote 20).

${ }^{7}$ The status of forms as thoughts of god is not explicit in Plato, although it can be sensed in a liberal interpretation of Timaeus 39e. However, given the absence of such a formulation in Plato, this can be considered as purely Alcinous' intervention.

${ }^{8}$ In the description of god as ineffable and without predicates (neither poios nor apoios) Merlan locates Alcinous closer to Plotinus' One than to Aristotle's god. Plotinus would agree that the supreme god should not be called good, for it would imply that he participates in goodness, while Alcinous easily describes the ineffable god as a thought that intelligizes itself and the forms, which perhaps anticipates Plotinus' stance on the intelligible not being external to intelligence (Enn. v, 5 [36]), in Merlan, 1967, 67.
} 
ontological concept is more developed in this sense, but begins with a similar argumentation), and it could be argued that inspire some of the Christian doctrines of the Logos.

Opinions are divided on the matter whether Alcinous had anticipated the NeoPlatonic doctrine of the One. In the editions of Philosophie des Altertums until 1925, K. Praechter answered affirmatively, claiming that an anticipation of the One can be located in Alcinous (Ueberweg, Praechter, 1953, 542). P. E. Witt denied even a trace of a definition of god as the One (Witt, 1937, 126, 128, 143 sqq), and similar strong doubts were expressed by H. J. Kraemer (Kraemer, 1964, 374) and J. Whittaker (Whittaker, 1969, 112). It appears that Mortley interchanges god and the One in Alcinous' theology, without paying attention to the matter. ${ }^{9}$ According to K. Kleve, these statements concerning the relationship between god and the One are very poorly substantiated with references to Alcinous' text, although in this sense younger scholars refer more to what Alcinous had not expressed (Kleve, 1972, 66-69). Kleve proposes a different angle in translating the aforementioned formulation of 10. 3: the First God is eternal, ineffable, full in itself, without needs ... He is Divinity, Being, Truth, Symmetry, the Good; as well as that Alcinous stresses that he does not say these things to distinguish His attributes, but under the assumption that god in relation to everything is understood as the One (67). ${ }^{10}$ The set of "these things" can apply to both "these terms" and "his attributes", and of course, since the continuity is quite clear, he is talking about the First god. Still, just because it can be read as "understood as one" (henos nooumenou), it does not necessarily imply that he means a particular One, in the sense later developed by neoPlatonist philosophers. Kleve himself allows for the possibility that Alcinous simply intended that God, different appellations notwithstanding, should be considered as one (thing), or that all of the divine attributes should be seen as one concept (67), and yet comes back to the need to not overlook the possibility that Alcinous offers a third option - the first god intended as the One (68). Alcinous equates god and the Good, and if the usage of articles in his text and in Plato is examined, it can be surmised that, while it would have been much easier to understand what he truly meant, had he used ton henos, the reason he did not is because attention to such distinctions was just not necessary in his time, Kleve suggests. If Plato used the determinate article in the discussion on the One in Parmenides, and if Alcinous employed it when listing some of Plato's arguments; if Plotinus interchangeably used hen and to hen in the Enneads to denote what we consider to be the One, then it is quite possible that Alcinous did the same (68). ${ }^{11}$ If that is the case, it remains unclear why Alcinous would leave such an important aspect of his ontological system as vague and obscure. ${ }^{12}$

\footnotetext{
${ }^{9}$ For example, one formulation he offers - “... God or the One, to Albinus is beyond thinking and perception in the ordinary sense" (Mortley, 1986b, 17).

${ }^{10}$ Kraemer, for example, leaves henos nooumenou - understood as one, without further elaborating on the options (Kraemer, 1964, note 3, 108).

${ }^{11}$ In Kleve's question on whether it is not possible to use to hen in the translation, given that, generally speaking, the usage of agathon and kalon in a predicative position excludes the need for
} 
God is the Good, ${ }^{13}$ which benefits all things, for he is the cause of everything that is good. He is the Beautiful, for he is perfect and commensurable by nature; he is Truth, as a source of everything true (of all truth). ${ }^{14}$ Alcinous explains that god is father through being the cause of everything, and bestowing order on the heavenly intellect and the cosmic soul, in accordance with himself and his own thoughts. He has filled all things with himself by his will, stirring the cosmic soul and directing it towards him-

an article, which opens up the possibility to use hen in the same way, especially since Alcinous' contemporaries would not have needed the article to understand what he was aiming at, Carbaine finds some faults. It is unclear whether a clarification about the (lack of) use of the definite article would be unnecessary, she claims. Plotinus always seemed to have the need to make a distinction between agathon and to agathon, hen and to hen, and it is a question why Alcinous would not have had such a need for grammatical and methodological clarity. If Alcinous meant to hen, he would have simply written to hen, she summarizes (Carabine, 1995, 82). She finds Kleve's step in identifying god with the One, wherein the identification with hen arises, to be forced, for it is not an equation present in Plato, nor even remotely present in Alcinous. God is interchangeably nous (intellect), and while this points to unity/singularity, it still does not make it an explicit reference to the One (83). According to Carabine (78), the reason why Alcinous does not refer to "The One" (if it was an intentional use of a formulation from Parmenides, it is unclear why he would ignore to hen appellations) is the need to defy the pythagorization of Platonism: god in Alcionus is not understood as a personal god, but a metaphysical principle, and the attempt to read Plato without a Pythagorean prism resulted in the rejection of to hen.

${ }^{12}$ Right after the discussion on the use of definite articles and the non-existent need to underline differences for the contemporaries, Kleve moves to the mathematical illustrations of the problem of knowledge of god, where he explains knowledge through abstraction - we reach the concept of a point through a successive abstraction from body to plain, to line, and to point. Kleve then reminds us that Alcinous, too, depicts god as partless, to then conclude, without elaboration, that these thoughts would be adequate in a speculation about god as the One (Kleve, 1972, 69).

${ }^{13}$ Dillon notices that the characterization of god as agathon ("the Good", neuter) is an apparent merger of the Republic 6 509b with Timaeus 29e (the Demiurge is good - agathos, masculine, Alcinous, Dillon, 2002, 106).

This difference between the neuter and the masculine adjective allows Numenius to make the distinction between the Good in Republic and the Demiurge in Timaeus (fr. 16), where the supreme principle is agathon, whilst the secondary god, the Demiurge, only participates in the Good, which makes it agathos. Alcinous explicitly denies (156. 7-8) that god is good because he participates in the goodness, he is Good because he is the cause for the goodness in everything good.

${ }^{14}$ These have been probably inspired by Philebus 65a, a part probably popular with the middle Platonists and the neo-Platonists, although in this case Beauty is not included in the enumeration (the formulation is that god is the Beautiful), but it can be assumed as an associated characteristic, especially having in mind that Alcinous later refers to beauty and symmetry, as if it had been already mentioned. God causes (or produces) goodness and beauty in other things, but he is Beauty not because he causes it, but through his perfection and commensurability; god is Father because he is the cause of being and of order of all things. Some overlap might be noticed between the Good of Republic and Philebus 65a-66b with the Demiurge of Timaues, if it is the supreme principle. 
self, for he is the cause of its intellect, which, given its order by the Father, in turn imposes order on all of nature of this world (10. 3/164 34-46)..$^{15}$

God is ineffable and graspable only by the intellect, Alcinous reiterates, for he has no genus, nor species, nor differentia, possesses no attributes, neither bad (for such and utterance would be inappropriate), nor good (for then through participation he would be in something). God, additionally, is not indifferent (for this would differ from our concept of him), is not qualified (for he is neither endowed with qualities, nor is his peculiar perfection due to some external qualification), but neither unqualified (for he is not deprived of some qualification he could have, that would have accrued to him, but did not, 10.3/165 5-15). ${ }^{16}$

The negative method of obtaining knowledge of the nature of God in Alcinous is represented by a negation of a series of qualities of god, and with an attempt to place the superiority of god over proposed pairs of opposing qualities. The formulation about god as ineffable resembles Timaeus 28a, but it also differs in that the intellect (nous) with which the first principle is grasped, is sort of an intuitive knowledge beyond Logos. All logical categories in accordance with which a definition could be formulated (genus, species and differentia), are denied by Alcinous in relation with the first principle, which has none of them, nor has it any accidental attributes, which makes it nondefinable.

It is significant that god is not deprived of any qualification he might have, and in this sense the pair qualified-unqualified functions through the negation apoios. God is not a part of anything, nor is he in a position to be a whole with parts, he is not the same as anything, nor is he different from anything (as he has no attributes with which

\footnotetext{
${ }^{15}$ There is a question on the type of distinction Alcinous is trying to establish by presenting god as either intellect (nous) or one that possesses intellect (noeron). Whittaker claims that this is of great importance for the Neo-Platonist metaphysical structure (Alcinous-Whittaker/Louis, 1990, 99, no. 163), with which Dillon disagrees (Dillon, 2002, 99), considering this view to be overly optimistic - for him, Alcinous just vaguely formulates that god is either an intellect or an entity that has intellect (is capable of intelligizing).

Nevertheless, if such an intelligizing entity is postulated, the question about its nature arises, as well as whether this formulation (either-or, god which is intellect/god who has intellect), is in any relation to the distinction between a primary and a secondary god.

${ }^{16}$ Dillon thinks that the charasterisation of god as more or less beyond the possibility for description has lead some interpreters to wrongly assume that Alcinous determines the primary deity as quite simply ineffable (101). This is wrong, Dillon asserts, because it is not something that Alcinous is trying to do - in his careful characterization Alcinous agrees with Timaeus 28c (that to discover the maker and father of the universe is indeed a task, and once discovered, to declare him unto all men is impossible). Plato perhaps means that the maker cannot be revealed to everyone, but only to few, and also in a broader sense, he might be referring to the verbal inexplicability of the true nature of the creator and father.
} 
the comparisons and differentiations with other things could be made). Also, he does not move anything, nor is he moved himself (10. 4/165 5-17). ${ }^{17}$

God is partless, for there was nothing before him - the part, or rather, that which constitutes a thing, exists before the thing which it constitutes (just as the plain precedes the body, and the line precedes the plain). ${ }^{18}$ Due to not having parts, god is immobile, both in terms of locomotion (like physical replacement, change of location), and qualitative change. ${ }^{19}$ If he were subject to change, that would have to be in accordance with his own agency (which would mean that he changes for the better, or for the worse, and both options are absurd), or due to the agency of someone else (which would make that someone more powerful -10.7/165 34-42). It is clear from all this, Alcinous states, that god is incorporeal. He adds, still, another way of describing god as incorporeal: if he were a body, it would have to be a combination of matter and form, with likeness to the Forms, and a participation in the forms difficult to explain, but it is absurd for god to be composed of matter and form, for he would then be neither simple, nor primordial (10.7/166 1-6).

The first way in which some concept of god may be obtained, Alcinous suggests, is through an abstraction of the attributes - just as we form a conception about a point, for example, by abstraction of all sensible phenomena, conceiving first a surface, then a line, and finally a point (10.5/165 18-21). The second way is through analogy: the sun's relation to seeing and to visible objects (it is not sight itself, but imparts seeing to the sight and visibility to objects) is like the one between the primary intellect and the soul's power of intellection. The primary intellect is not the power of intellection itself, but rather it bestows intellection to the soul (it provides intelligibility to the objects of intellection, by illuminating the truth they contain - 10.5/165 20-26). ${ }^{20}$

\footnotetext{
${ }^{17}$ If he is unmoving, then there is a divergence from the Aristotelian concept of the unmoved mover. If the primary god is an unmoved mover, the cause for the entire movement of the heavenly intelligences (just as the object of desire moves desire towards it), then Aristotle's influence is obvious, in a Platonist system in which Beauty, as the most appropriate place for the nous, is at the top of the hierarchy, which is a typical example for a middle Platonist fusion.

${ }^{18}$ This is reminiscent of the One as partless in Parm. 137c5, and indubitably the definition of the point in Euclides (the very first definition of the System of Elements, see Festugière, 1954, 100).

${ }^{19}$ In the explanation of god as partless, Alcionus diverges from the argumentation by Parmenides in On nature, for example, but also from Plato's stance in Parmenides (see also Sophist 245a1), which refers to the unity of the One. According to Alcinous, there would have to exist something before the thing that has parts (logically and temporally), and in this sense the argumentation is associated with the geometrical examples of aphairesis, according to which the point has no parts, by which it precedes the line, the plain, and the body, and is unpreceded itself.

${ }^{20}$ The Form of the good is compared to the sun in the Republic (508a-c), in the sense that it allows us to see things - the sun is described as the cause of sight, not sight itself. The Good bestows truth in the things known, and the power to know in the knower. Festugière notices that the argument of knowledge by analogy is "almost literally the same as in the Republic 508b12-c4" (Festugière, 1954, 99). The analogy between the primary intellect (or god) and the sun, can obvi-
} 
The third way of conceiving god is through the contemplation of beauty in bodies, then turning to the beauty of the soul, beauty in customs and laws, to the "great sea of Beauty", after which intuition about the Good itself and the final object of love and striving is gained, shining out to the soul that is ascending this path. Along this, Alcinous further explains, intuition of god is achieved by virtue of his pre-eminence in honour (10.6/165 28-34). ${ }^{21}$

The ascent toward beauty, in order to reach the notion of the Beautiful itself and become a friend of god, in Plato is used as an explanation of the general problem of obtaining knowledge about the existence of the form of the Beauty (like in the previously mentioned case with the Good), while in Alcinous it is used to explain how it can be spoken about god. Just as all natural individual objects of sense perception need to have certain models - the Forms that serve as objects of scientific knowledge and of definition, so the most beautiful of constructions, the world, must have been created by god, with reference to the Form of the world (by referring to Timaeus 29e, Alcinous explains that the Maker creates the world with care and dedication, by assimilating the model, which is the Form of the world, 12.1/166 40-43; 167 1-15). The Maker created the world

ously be compared to Plato's analogy of the Form of the good as cause of both knowledge and truth, without it being truth or knowledge itself, and the sun, which provides creation, growth and nurturing, without it being creation itself. While in the case of Plato the analogy is used as an explanation for the general problem regarding the way to reach knowledge about the existence of the Form of the good, in Alcinous it is probably used as a way of explanation on how to talk about god. God is essentiality not something that can be talked about, suggests Alcinous, but what can be talked about is his causal relation to the world, or his actions within the world, through which his existence is also talked about.

${ }^{21}$ The placement of Beauty above the Good is an unusual move. Besides, the primary god is in the realm of Beauty, above nous, a feature present only in Celsus, until it is seen in Plotinus. It is problematic that Alcinous uses intellect (nous) and god, like they are interchangeable in the exposition of Plato's theology, which does not help clarify the intended status of the primary god - he is the maker of nous, but it remains unclear whether (or, better, how) he is placed above nous.

Dillon summarizes that Alcinous illustrated the analogy through the sun simile from the Republic 508b-509b, the hyperoche (pre-eminence) from Diotima's discourse on the ascent towards the Beautiful itself from Symposium 210a sqq, with a reference to Aristotle's unmoved mover as an object of striving (Metaph 12.7. 1072a26, compare Ph. I. 9. 192a1), and (probably) an allusion to Plato's famous example of knowledge that appears in the soul as suddenly as a light kindled by a leaping spark from the fire (Letter Seven, 341c-d).

Carabine assesses that the dry writing and the subject of investigation in Didaskalikos suggest that Alcinous was not particularly focused on speculative theology; his descriptions of the way towards knowledge of god lack the mystical feeling which is present in, for example, Maximus of Tyr and Celsus (73). According to Dillon, Alcinous exhibits clear mystical tendencies in chapter X (Dillon, 1996, 268). The exposition on the nature of god gives off the impression that he conceived god as a metaphysical principle that needs to be neatly positioned within the entire scheme of existence (Carabine, 1995, 73), with the Handbook following the traditional (originally Stoic) division into logic, physics and ethics, wherein chapters on theology pertain to the physics section. 
from the totality of matter - as he moved randomly and without order, before the creation of heavens, he bestowed best possible order in the four elements, adorning its parts with suitable numbers and shapes, without leaving out any part of potency of any of them. By not leaving anything outside of the world, the Maker has rendered it unique and numerically likened to its form; self-sufficient and in no need of any external help (12. 2-3/167 15-45). ${ }^{22}$ The three ways that Alcinous lists as possibilities for gaining some concept of god are, in summary, negation or abstraction (aphairesis), or the later via negationis; analogy (analogia), via analogiae; and a way he does not name clearly, but which can be thought of as pre-eminence (hyperochē, following the concluding remark on pre-existence), or the later via eminentiae.

It seems that Alcinous employs a purely Greek theory of aphairesis - in order to arrive to some knowledge of god, abstraction should be used, which is later a major part of the soul's journey back into the One in the Enneads (and also in some of the early Church Fathers). A. H. Armstrong considers Alcinous' method of abstraction to be a large and undigested lump of negative theology, unfitted and foreign in his system (Armstrong, 1984, 11-15; Armstrong, 1940, 23). Carabine does not agree with Armstrong (78), wondering why aphairesis should be considered a foreign and forced method in Alcinous, but be accepted as an integrative part of Plotinus' negative theology, especially since, even if it does look undigested in Alcinous, one should have in mind the nature of the text - a condensed teachers' manual. ${ }^{23}$ Wolfson traces the use and meaning of Alcinous' aphairesis in Euclides (Wolfson, 1952), while, according to Whittaker, it has a Pythagorean origin (Whittaker, 1969). Carabine, taking into account Aristotle's use of the geometrical symbolism in On the soul, and the movement from sense perception towards the intellect, suggests that the origin should be located in Aristotle (Carabine, 1995, 79). Aphairesis in Aristotle refers to (sub)traction, while in Alcinous and Plotinus, according to Wolfson, it has acquired a technical meaning of 'negation in a logical inference' (the wall is non-seeing, as opposed to man, who is blind, for example, 1952, 120-121). For Whittaker, apophasis in Aristotle is simply a general term for negation, and not a sort of a technical substratum, and with that, an underlying reason for the use of abstraction in Alcinous, in whose concept the importance lies in creating some

\footnotetext{
${ }^{22}$ Other deities, daemons or "created gods", are included in Alcinous' ontological concept present in each of the elements, some visible and some invisible, so that no part of the world should be without a share in soul, and in a living creature superior to the mortal nature. The whole sublunar and terrestrial world has been assigned to their administration (15.1/171 15-21).

God himself is the creator of the universe, of gods and of demons, and because of this the universe allows for no dissolution, Alcinous posits. The rest is ruled over by his children, who act in accordance with his commands and in imitation of him. Omens and presages derive from them, as well as dreams and oracles, and all the artificial divination practiced by mortals (15.2/171 2227).

${ }^{23}$ If this 'undigested' qualification is accepted, then it can be considered that, since a 'relation' with the god in Didaskalikos is not mentioned, the negative theology is certainly not fully fledged (which is not in the least surprising for that period and intellectual tradition).
} 
sort of a concept of God, and not in the problem of logical formulation of negative statements (Whittaker, 1969, 123). Carabine inclines more towards Whittaker than towards Wolfson (Carabine, 1995, 79), pointing to a remark made by Alcinous in chapter IV - he lists only the positive and negative methods in formulating propositions, supporting it with examples like "Socrates walks" and "Socrates does not walk" (she provides VI, 1 for reference, but she might mean IV, 1). Mortley reminds us of the use of aphairesis in Aristotle, which has a metaphysical purpose - it is the way of subtraction of successive layers in order to find the first principle, subtraction leads to the essence (or whatness) of things (Mortley, 1986a, 137-140). Also, apophasis for Aristotle is aphairesis for Alcinous. Mortley makes a point - abstraction may perhaps be a form of negation, but it is a form of privation, and in this sense abstraction and negation are not identical in that they differ in purpose, not technique (Mortley, 1986b, 179). According to Mortley, Aristotle discards the method of apopohasis because of its lack of definitiveness, for to say of something that "it is not good", implies that everything but goodness can be predicated to that subject, which means it is not a suitable way to arrive to the essence of things. Steresis deprives, and apophasis opens different possibilities (except in, for example, the case of oneness, for to negate oneness means to imply multitude). Mortley, thus, assesses that aphairesis as a method to reach the unknown in Aristotle facilitated the later reconstruction of some of Plato's stances, which made it instrumental in the development of the neo-platonic negative theology. According to Carabine, aphairesis used by Alcinous is a means by which the supreme god rises above the material world of genera and species, which she later locates in Pseudo-Dionysius, as a way to abstract from god's nature all attributes that pertain to created creatures. In Alcinous, she recaps, aphairesis remains on the level of intellect (not rising beyond nous), does not strive for any supra-intellectual knowledge of god, because of which it resembles more via remotionis (a future scholastic concept), a rational positioning of god above and beyond the world of created nature (Carabine, 1995, 80). When discussing Alcinous and Plotinus, Wolfson reminds us that not only can god be described by predicates negative in form, but also predicates that are positive, provided they are understood as negative in their meaning $(1952,125)$. This is not explicitly stated, but can be gathered from the descriptions of god that Alcinous provides (like complete in itself, in the sense that he is not in want of anything). God for Alcinous is the good and truth, in the sense that he is the cause of every good, and the principle (arhé) of every truth.

Alcinous' account of god might be considered apophatic, or almost-apophatic (depending on how broad the definition of the negative approach in knowing god is). A concept of God is somewhat attainable through abstraction of attributes, a process that, like in almost all of the second century Platonism, does not lead to mystical experiences, but is instrumental in the further development of negative theology. 


\section{References}

Albinos. (1945). Epitome. Pierre Louis, trans., Paris: Les Belles-Lettres.

Alcinous. (1990). Alkinoos, Enseignements des doctrines de Platon. John Whittaker, ed., Pierre Louis, trans., Paris: Collection des Universités de France, Belles Lettres.

Alcinous. (2002). The Handbook of Platonism. John Dillon, trans., Oxford: Clarendon Press.

Aristotle. (1966). Metaphysics. H. Apostle, trans., Bloomington: Indiana University Press.

Aristotle. (1987). De Anima (On the Soul). Hugh Lawson-Tancred, trans., London: Penguin Classics.

Armstrong, A. H. (1940). The Architecture of the Intelligible Universe. Cambridge: Cambridge University Press.

Armstrong, A. H. (1984). L'architecture de l'univers intelligible dans la philosophie de Plotin. Une étude analytique et historique. Ottawa: Éditions de l'Université d'Ottawa.

Carabine, D. (1995). The Unknown God. Louvain: Peeters Press.

Dillon, J. M. (1996). The Middle Platonists. Ithaca: Cornell University Press.

Festugière, A-J. (1954). La révélation d'Hermès trismégiste, vol. 4 - Le dieu inconnu et la gnose. Paris: Gabalda.

Freudenthal, J. (1879). Der Platoniker Albinos und der falsche Alkinoos. Berlin: S. Calvary \& Co.

Kleve, K. (1972). Albinus on God and the one. Symbolae Osloenses, 47:1, pp. 66-69.

Kraemer, H. J. (1964). Der Ursprung der Geistmetaphysik. Amsterdam: B. R. Grüner.

Merlan, P. Greek Philosophy from Plato to Plotinus. In A. H. Armstrong, ed., The Cambridge History of Later Greek and Early Medieval Philosophy. $1^{\text {st }}$ ed. Cambridge: Cambridge University Press, 1967, pp. 14-135.

Mortley, R. (1986). From Word to Silence, vol. 1. The Rise and Fall of Logos. Bonn: Hanstein.

Mortley, R. (1986). From Word to Silence, vol. 2. The Way of Negation, Christian and Greek. Bonn: Hanstein.

Numénius. (1973). Fragments. E. Des Places, trans., Collection Budé, Paris: Les Belles Lettres.

Plato. (1997). Complete Works. John M. Cooper, ed., Indianapolis: Hackett Publishing Company.

Ueberweg, F, and Praechter, K. (1953). Die Philosophie des Altertums. Basel: Benno Schwabe \& Co.

Whittaker, J. (1969). Neopythagoreanism and negative theology. Symbolae Osloenses, 44:1, pp. 109-125. 
Whittaker, J. (1974). 'Parisinus Graecus 1962' and the Writings of Albinus. Phoenix, Vol. 28, No. 3, pp. 320-354.

Whittaker, J. (1974). 'Parisinus Graecus' 1962 and the Writings of Albinus: Part 2. Phoenix, Vol. 28, No. 4, pp. 450-456.

Witt, R. E. (1937). Albinus and the history of Middle Platonism. Cambridge: Cambridge University Press.

Wolfson, H. A. (1952). Albinus and Plotinus on Divine Attributes. The Harvard Theological Review, Vol. 45, No. 2, pp.115-130 